\title{
ANALISIS PERMINTAAN DAN PENAWARAN MAKANAN KHAS LANGKITANG DI PANTAI PADANG
}

\author{
Waryono $^{1}$, Youmil Abrian ${ }^{1}$, Hijriyantomi Suyuthie ${ }^{1}$ \\ ${ }^{1,}$ Dosen Jurusan Pariwisata Fakultas Pariwisata dan Perhotelan \\ Universitas Negeri Padang \\ Email.waryono19812012@gmail.com
}

\begin{abstract}
Padang Beach has a typical culinary tour like Langkitang. Typical food is one of the factors supporting a region's famous. This study aims to analyze the demand and supply of typical food langkitang in Padang Beach. In particular it aims to analyze the market balance that is influenced by the price of the goods itself, the price of the substitute, the consumer's income, the number of buyers, the cost of production, and the number of producers in the market. The type of research conducted in this study is the type of descriptive quantitative research by survey method. The population of this study are visitors who buy typical food Langkitang and typical food vendors Langkitang which has a stall in the area of Padang Beach. The sampling technique used is purposive sampling, the buyer is 10 people based on the number of samples from the merchant as many as 10 people, with the assumption that 1 trader 1 buyer. Data collection techniques used were observation, interview, documentation, and questionnaire. The data obtained will be analyzed and interpreted in accordance with the objectives and research hypotheses that have been proposed. The analysis was conducted using simultaneous equation model and market balance equation method. Based on the results of this study can be emphasized that the demand and supply of typical food Langkitang in Padang Beach has reached the point of market balance, which is at the equilibrium price of Rp. 4,600, - the proportion with the balance quantity of 32 servings. This means that the equilibrium price will determine the quantity of balance between demand and supply of typical food of Langkitang in Padang Beach. Break event point is on sale of 21 servings of Langkitang with revenue of Rp. 105.000, -.
\end{abstract}

Keywords: Langkitang, Demand, Supply.

\section{PENDAHULUAN}

Kota Padang memiliki beberapa objek wisata pantai dengan keindahan yang berbeda-beda salah satu objek wisata andalan adalah Pantai Padang yang juga dikenal dengan sebutan Taplau (Tapi Lauik). Karena sangat mudah untuk dicapai sehingga selalu dipadati warga kota Padang yang ingin menyegarkan pikiran dari segala runtinitas sehari-hari, maupun para pelancong yang kebetulan berwisata atau dalam rangka urusan bisnis di Kota Padang. Disepanjang pantai terdapat warung-warung tenda berdiri berjejer di tepi pantai, terutama pantai yang didekat tugu IORA hingga pantai Muaro Lasak. Keindahan sepanjang garis Pantai Padang dapat dinikmati dari dengan sepeda santai, berjalan kaki, dan dengan transportasi lokal seperti kereta pantai (odongodong). Pantai Padang selalu dipadati pengunjung, terlebih sejak dibangunnya sebuah monumen IORA, Tulisan Kota 
Padang dan Monumen Merpati Perdamaian sehingga banyak pengunjung yang datang baik hanya untuk berfoto atau menikmati susana sore hari di tepi pantai. Sehingga memberikan dampak terhadap peningkatan jumlah kunjungan ke objek wisata Pantai Padang.

Makanan khas merupakan salah satu faktor pendukung terkenalnya suatu daerah. Dimana makanan tersebut biasanya memiliki ciri khas atau spesifik dari suatu daerah, sesuai dengan pendapat Winarno dalam Puspita

(2015:8), menyatakan bahwa "Makanan khas atau makanan tradisional merupakan makanan yang pekat dengan tradisi dan ciri khas daerah setempat". Pantai Padang memiliki wisata kuliner yang khas seperti Langkitang. Langkitang merupakan makanan khas berupa sejenis keong yag sering disebut dengan langkitang yang dimasak dengan kuah gulai. Langkitang memiliki ciri khas bumbu gulainya. Langkitang diolah dengan cara cuci bersih langkitang setelah bersih masukkan langkitang kedalam kuah gulaiyang mendidih yang terdiri dari campuran santan kelapa kental, cabe, laos, kunyit, jahe, bawang merah dan bawang putih yang telah dihaluskan. Untuk mengurangi bau amis ditambahkan dengan daun jeruk nipis dan asam kandis.

Tabel 1. Penjualan Makanan Khas langkitang di Pantai Padang

\begin{tabular}{|c|c|c|c|}
\hline Kode Pedagang & Rata-rata diproduksi & Rata-rata terjual & Rata-rata tersisa \\
\hline A01 & 10 liter & 8 liter & 2 liter \\
\hline A02 & 14 liter & 10 liter & 4 liter \\
\hline $\mathrm{A} 03$ & 10 liter & 9 liter & 1 liter \\
\hline A04 & 15 liter & 11 liter & 4 liter \\
\hline \multicolumn{2}{|c|}{ Rata-rata/hari } & 38 liter & 11 liter \\
\hline
\end{tabular}

Sumber: Wawancara Peneliti (2017).

Berdasarkan tabel di atas, dapat dilihat bahwa makanan khas langkitang yang diproduksi oleh masing-masing pedagang, rata-rata setiap harinya tidak habis terjual. Hasil wawancara peneliti, beberapa pedagang menyatakan makanan khas langkitang yang tersisa akan di simpan dilemari es dan dipanaskan kembali untuk dijual keesokan harinya.

Melihat fenomena tersebut perlu diketahui bagaimana tanggapan wisatawan dan pedagang makanan khas langkitang terhadap kondisi permintaan dan penawaran makanan khas langkitang yang ada di objek wisata Pantai Padang. Untuk menghindari dampak jangka panjang yang ditimbulkan, seperti wisatawan tidak mau membeli makanan dan minuman yang dijual karena belum adanya standarisasi harga dari produk yang ditawarkan tersebut. Dengan demikian penjual hanya akan meramaikan pasar sementara makanan yang ditawarkan tidak habis terjual dan omset tidak tercapai. 
Secara khusus penelitian ini bertujuan untuk menganalisis keseimbangan pasar yang dipengaruhi oleh harga barang itu sendiri, harga barang pengganti, pendapatan konsumen, jumlah pembeli, biaya produksi, dan jumlah produsen dipasar.

\section{METODE PENELITIAN}

Jenis penelitian yang dilakukan dalam penelitian ini adalah jenis penelitian deskriptif kuantitatif dengan metode survei.

Data yang diperoleh akan dianalisis dan diinterpretasikan sesuai dengan tujuan dan hipotesis penelitian yang telah dikemukakan. Teknik analisis data yang digunakan adalah analisis deskriptif dan analisis induktif. Analisis deskriptif disajikan dalam bentuk tabel distribusi penyebaran data dari variabel yang diteliti kemudian dilakukan analisis presentase, serta memberikan interpretasi terhadap analisis tersebut. Analisis induktif dilakukan dengan menghitung model persamaan silmultan dan metode analisis keseimbangan pasar.

Langkah-langkah untuk menentukan persamaan simulatan atau untuk mencapai keseimbangan adalah sebagai berikut:

1) Menentukan spesifikasi model persamaan original untuk permintaan dan penawaran. Model persamaan original dalam penelitian ini adalah sebagai berikut:

a) Untuk persamaan Permintaan:

$\mathrm{Q}_{\mathrm{d}}=\mathrm{f} \quad\left(\mathrm{P}, \quad \mathrm{P}_{\mathrm{S}}, \quad \mathrm{Y}\right.$,

N)...
$\mathrm{Q}_{\mathrm{d}}=\mathrm{a}_{0}+\mathrm{a}_{1} \mathrm{P}+\mathrm{a}_{2} \mathrm{P}_{\mathrm{S}}+\mathrm{a}_{3} \mathrm{Y}+\mathrm{a}_{4} \mathrm{~N}+$

$\mu_{1}$

$\mathrm{Q}_{\mathrm{d}}=\mathrm{P}^{\alpha 1} \mathrm{P}_{\mathrm{S}}{ }^{\alpha 2} \mathrm{Y}^{\alpha 3} \mathrm{~N}^{\alpha 4} \mathrm{e} \mu 1$

Kemudian model tersebut dapat ditranformasikan kedalam persamaan logaritma :

$\operatorname{Ln} \mathrm{Q}_{\mathrm{d}}=\mathrm{a}_{0}+\mathrm{a}^{1} \operatorname{Ln} \mathrm{P}+\mathrm{a}_{2} \operatorname{Ln} \mathrm{P}_{\mathrm{S}}+\mathrm{a}_{3}$

$\operatorname{Ln~Y}+\mathrm{a}_{4} \operatorname{Ln} \mathrm{N}+\mu_{1}$

Dimana :

$\mathrm{Q}_{\mathrm{d}}=$ Permintaan makanan khas Langkitang

$\mathrm{P}=$ Harga makanan khas

Langkitang

$\mathrm{P}_{\mathrm{S}}=$ Harga Pensi sebagai barang substitusi

$\mathrm{Y}=$ Pendapatan Konsumen

$\mathrm{N}=$ Jumlah Pembeli

$\mathrm{a}=$ Parameter estimasi

b) Untuk persamaan Penawaran :

$\mathrm{Q}_{\mathrm{s}}=\mathrm{f}(\mathrm{P}, \mathrm{Ps}, \mathrm{C}, \mathrm{Tp})$

$\mathrm{Q}_{\mathrm{s}}=\beta_{0}+\beta_{1} \mathrm{P}+\beta_{2} \mathrm{P}_{\mathrm{S}}+\beta_{3} \mathrm{C}+\beta_{4} \mathrm{Tp}$

$+\mu 2$

$\mathrm{Q}_{\mathrm{s}}=\mathrm{P}^{\beta 1} \mathrm{P}_{\mathrm{S}}^{\beta 2} \mathrm{C}^{\beta 3} \mathrm{Tp}^{\beta 4} \mathrm{e} \mu_{2}$

Kemudian model tersebut dapat ditranformasikan kedalam persamaan logaritma :

Ln $\mathrm{Q}_{\mathrm{s}}=\beta_{0}+\beta_{1}$ Ln $\mathrm{P}+\beta_{2}$ Ln $\mathrm{P}_{\mathrm{S}}+\beta_{3}$ Ln $C+\beta_{4} \operatorname{Ln} \mathrm{Tp}+\mu$

Dimana :

$\mathrm{Q}_{\mathrm{s}}=$ Penawaran makanan khas Langkitang

$\mathrm{P} \quad=$ Harga makanan khas Langkitang

$\mathrm{P}_{\mathrm{s}}=$ Harga Pensi sebagai barang substitusi

$\mathrm{C}=$ Biaya produksi

$\mathrm{Tp}=$ Jumlah Produsen dipasar/ pesaing

$\beta=$ Parameter estimasi

2) Menentukan persamaan struktural atau persamaan simultan. 
Persamaan simultan disusun dengan cara mensubstitusikan $P$ fit ke dalam persamaan original (9) dan (10) hal ini dilakukan untuk mencari nilai keseimbangan.

$\operatorname{Ln} \mathrm{Q}_{\mathrm{d}}=\mathrm{a}_{0}+\mathrm{a}_{1} P$ fit $+\mathrm{a}_{2} \operatorname{Ln} \mathrm{P}_{\mathrm{S}}+\mathrm{a}_{3}$

$\operatorname{Ln} \mathrm{Y}+\mathrm{a}_{4} \operatorname{Ln} \mathrm{N}+\mu 1$

Ln $Q_{s}=\beta_{0}+\beta_{1} P$ fit $+\beta_{2}$ Ln $P_{\mathrm{S}}+\beta_{3}$

Ln $\mathrm{C}+\beta_{4} \operatorname{Ln} \mathrm{Tp}+\mu_{2}$

3) Mencari nilai keseimbangan

Untuk mencari nilai keseimbangan adalah $\mathrm{Q}_{\mathrm{d}}=\mathrm{Q}_{\mathrm{s}}$

Maka persamaan (15) dan (16) diubah menjadi anti -ln

Ln $\mathrm{Q}_{\mathrm{d}}=\mathrm{a}_{0}+\mathrm{a}_{1}{ }^{1} P$ fita $^{2}+\mathrm{a}_{2} \operatorname{Ln} \mathrm{P}_{\mathrm{S}}+$ $\mathrm{a}_{3} \operatorname{Ln} \mathrm{Y}+\mathrm{a}_{4} \operatorname{Ln} \mathrm{N}+\mu 1$

Ln $Q_{s}=\beta_{0}+\beta_{1}{ }^{1} P$ fita ${ }^{2}+\beta_{2}$ Ln $_{\mathrm{S}}+\beta_{3}$

$\operatorname{Ln} C+\beta_{4} \operatorname{Ln} \mathrm{Tp}+\mu$

Kemudian nilai mean $\mathrm{P}_{\mathrm{S}}, \mathrm{Y}$ dan $\mathrm{N}$ disubstitusikan ke persamaan $\mathrm{Q}_{\mathrm{d}}$. Sedangkan nilai mean $\mathrm{P}_{\mathrm{S}}, \mathrm{C}$ dan $\mathrm{Tp}$ disubstitusikan ke $Q_{s}$. Sehingga akan menghasilkan nilai $P$ fit dari $\mathrm{Q}_{\mathrm{d}}=\mathrm{Q}_{\mathrm{s}}$.

\section{b. Metode Analisis Kese- imbangan Pasar}

Keseimbagan pasar terjadi saat jumlah barang yang diminta sama dengan jumlah barang yang ditawarkan yang disebut dengan Equilibrium Price (E) atau Market Equilibrium. Menurut Pramutoko (2012: 86), "Analisis keseimbangan pasar dapat dilakukan melalui beberapa pendekatan sebagai berikut:

1) Pendekatan Matematika

Pendekatan

matematika digunakan dalam mencari harga dan jumlah keseimbangan apabila data

yang dimiliki berbentuk fungsi permintaan dan fungsi penawaran. Untuk mencari harga dan jumlah keseimbangan dari kedua fungsi tersebut, dapat menggunakan rumus syarat keseimbangan berikut: $\mathrm{Q}_{\mathrm{d}}=\mathrm{Q}_{\mathrm{s}}$ atau $\mathrm{P}_{\mathrm{d}}=\mathrm{P}_{\mathrm{s}}$

Dimana :

$\mathrm{Q}_{\mathrm{d}}=$ jumlah yang diminta

$\mathrm{Q}_{\mathrm{s}}=$ jumlah yang ditawarkan

$\mathrm{P}_{\mathrm{d}}=$ harga yang diminta

$\mathrm{P}_{\mathrm{S}}=$ harga yang ditawarkan

2) Pendekatan Grafik/ kurva

Untuk memperlihatkan secara jelas adanya harga dan jumlah keseimbangan dari tabel yang telah dibuat sebelumnya, perlu dibuat sebuah kurva permintaan dan penawaran. Dari perpotongan kurva permintaan dan penawaran didapat titik keseimbangan (E).

Pada kurva keseimbangan inilah dapat dilihat harga dan kuantitas keseimbangan secara jelas".

\section{HASIL DAN PEMBAHASAN}

\section{Hasil Penelitian}

Model analisis yang digunakan adalah persamaan simultan dengan metode Two Stage Least Squeres (2SLS). Berdasarkan teori, keseimbangan pasar terjadi 
pada saat jumlah barang yang diminta sama dengan jumlah barang yang ditawarkan pada tingkat harga keseimbangan. Pada penelitian ini diasumsikan bahwa jumlah makanan khas Langkitang yang diproduksi tidak sama besar dengan yang dikonsumsi pembeli. Sehingga permintaan makanan khas Langkitang lebih kecil dari penawaran makanan khas Langkitang yang ditawarkan pedagang di Pantai Padang.

Berdasarkan hasil pengolahan data menggunakan program SPSS.16 diperoleh hasil estimasi model persamaan simultan dengan hasil regresi pada tahap pertama berupa model persamaan simultan yang bersifat regresi biasa non struktural (simultan) adalah sebagai berikut:

\section{1) Menentukan Model Per- samaan Untuk Permintaan}

Pada penelitian ini setelah dilakukan beberapa uji asumsi klasik terhadap model regresi untuk data permintaan makanan khas Langkitang di Pantai Padang, kemudian dilakukan analisis persamaan simultan untuk data permintaan dengan menggunakan aplikasi spss.16. yang menghasilkan hasil penelitian sebagaimana pada tabel berikut:

Tabel 2. Hasil Estimasi Persamaan Simultan Untuk Permintaan

\begin{tabular}{|c|c|c|c|c|c|c|}
\hline & & \multicolumn{2}{|c|}{ Unstandardized Coefficients } & \multirow{2}{*}{ Beta } & \multirow{2}{*}{$\mathbf{T}$} & \multirow{2}{*}{ Sig. } \\
\hline & & B & Std. Error & & & \\
\hline \multirow[t]{5}{*}{ Equation 1} & (Constant) & 39.370 & 40.036 & & .983 & .001 \\
\hline & $\mathrm{P}$ & .890 & .067 & 2.784 & 1.336 & .039 \\
\hline & Ps & -.108 & .080 & -2.652 & -1.342 & .237 \\
\hline & Y & .880 & .000 & 1.146 & 2.386 & .036 \\
\hline & $\mathrm{N}$ & .115 & .343 & .117 & .335 & .751 \\
\hline
\end{tabular}

a) Analisa Regresi Untuk

\section{Permintaan}

Berdasarkan data pada tabel

maka dimasukan dalam

persamaan regresi berikut:

$\mathrm{Q}_{\mathrm{d}}=\mathrm{f}\left(\mathrm{P}, \mathrm{P}_{\mathrm{S}}, \mathrm{Y}, \mathrm{N}\right)$

$\mathrm{Q}_{\mathrm{d}}=\mathrm{a}_{0}+\mathrm{a}_{1} \mathrm{P}+\mathrm{a}_{2} \mathrm{P}_{\mathrm{S}}+\mathrm{a}_{3} \mathrm{Y}+$

$\mathrm{a}_{4} \mathrm{~N}+\mu_{1}$

$\mathrm{Q}_{\mathrm{d}}=\mathrm{P}^{\alpha 1} \mathrm{P}_{\mathrm{S}}{ }^{\alpha 2} \mathrm{Y}^{\alpha 3} \mathrm{~N}^{\alpha 4} \mathrm{e}^{\mu 1}$

Berdasarkan persamaan di atas dapat diketahui bahwa:

(1) Koefisien elastisitas dari harga makanan khas Langkitang (P) dalam persamaan regresi di atas adalah 0,890. Hal ini menunjukan bahwa nilai elastisitas perubahan harga dari makanan khas Langkitang berpengaruh secara positif dan signifikan.

(2) Koefisien elastisitas dari harga barang pengganti $\left(\mathrm{P}_{\mathrm{s}}\right)$ dalam persamaan regresi adalah $-0,108$. Hal ini menunjukan bahwa nilai elastisitas 
harga barang pengganti

ada pengaruh yang negatif.

(3) Koefisien elastisitas dari pendapatan konsumen (Y) dalam persamaan regresi adalah 0,880 .

Hal ini menunjukan bahwa nilai elastisitas tingkat pendapatan konsumen ada pengaruh yang positif dan signifikan.

(4) Koefisien elastisitas dari jumlah pembeli $(\mathrm{N})$ dalam persamaan regresi adalah 0,115 . Hal ini menunjukan bahwa nilai elastisitas jumlah pembeli ada pengaruh yang positif namun tidak signifikan.

(5) Hasil analisa regresi di atas menunjukan, bahwa permintaan makanan khas Langkitang di Pantai Padang dipengaruhi oleh harga $(\mathrm{P})$, dan pendapatan konsumen

(Y)

secara signifikan.

Berdasarkan hasil pengolahan data menggunakan program spss.16 diperoleh hasil estimasi model persamaan simultan dengan hasil regresi pada tahap pertama berupa model persamaan adalah sebagai berikut:

\section{1) Menentukan Model \\ Persamaan \\ Untuk}

\section{Penawaran}

Pada penelitian ini setelah dilakukan beberapa uji asumsi klasik terhadap model regresi untuk data penawaran makanan khas Langkitang di Pantai Padang dilakukan analisis persamaan simultan untuk data penawaran dengan menggunakan aplikasi spss.16. yang menghasilkan hasil penelitian sebagaimana dalam tabel berikut:

Tabel 3. Hasil Estimasi Persamaan Simultan Untuk Penawaran

\begin{tabular}{|c|c|c|c|c|c|c|}
\hline & & \multicolumn{2}{|c|}{ Unstandardized Coefficients } & \multirow{2}{*}{ Beta } & \multirow{2}{*}{$\mathbf{t}$} & \multirow{2}{*}{ Sig. } \\
\hline & & B & Std. Error & & & \\
\hline \multirow[t]{5}{*}{ Equation 1} & (Constant) & 27.991 & 15.223 & & 1.839 & .025 \\
\hline & $\mathrm{P}$ & .019 & .021 & .601 & .903 & .040 \\
\hline & Ps & -.024 & .024 & -.588 & -1.014 & .357 \\
\hline & $\mathrm{C}$ & .254 & .000 & -.393 & -1.743 & .042 \\
\hline & $\mathrm{Tp}$ & 1.241 & .167 & 1.072 & 7.440 & .001 \\
\hline
\end{tabular}

\section{a) Analisa Regresi Untuk}

Penawaran

Berdasarkan data pada Tabel 3. di atas, kemudian dimasukan dalam persamaan regresi berikut:

$$
\begin{aligned}
& \mathrm{Q}_{\mathrm{s}}=\mathrm{f}(\mathrm{P}, \mathrm{Ps}, \mathrm{C}, \mathrm{Tp}) \\
& \mathrm{Q}_{\mathrm{s}}=\beta_{0}+\beta_{1} \mathrm{P}+\beta_{2} \mathrm{P}_{\mathrm{S}}+\beta_{3} \mathrm{C}+\beta_{4} \mathrm{Tp} \\
& +\mu 2 \\
& \mathrm{Q}_{\mathrm{s}}=\mathrm{P}^{\beta 1} \mathrm{P}_{\mathrm{S}}{ }^{\beta 2} \mathrm{C}^{\beta 3} \mathrm{Tp}^{\beta 4} \mathrm{e}^{\mu 2}
\end{aligned}
$$


Berdasarkan persamaan di atas dapat diketahui bahwa:

(1) Koefisien elastisitas dari harga makanan khas Langkitang (P) dalam persamaan regresi adalah 0,019. Hal ini menunjukan bahwa nilai elastisitas perubahan harga dari makanan khas Langkitang berpengaruh secara positif dan signifikan.

(2) Koefisien elastisitas dari harga barang pengganti $\left(\mathrm{P}_{\mathrm{s}}\right)$ dalam persamaan regresi adalah -0,024. Hal ini menunjukan bahwa nilai elastisitas harga barang pengganti berpengaruh negatif.

(3) Koefisien elastisitas dari biaya produksi (C) dalam persamaan regresi adalah 0,254. Hal ini menunjukan bahwa nilai elastisitas biaya produksi ada pengaruh yang positif dan signifikan sebesar 0,254 .

(4) Koefisien elastisitas dari jumlah

produsen

dipasar/pesaing (Tp) dalam persamaan regresi adalah 1,241. Hal ini menunjukan bahwa nilai elastisitas jumlah produsen dipasar ada pengaruh yang positif.

(5) Hasil analisa persamaan regresi di atas, menunjukan bahwa penawaran makanan khas Langkitang di Pantai Padang dipengaruhi oleh harga $(\mathrm{P})$, biaya produksi $(\mathrm{C})$, dan jumlah produsen /pesaing (Tp) secara signifikan.

e. Hasil Analisis Keseimbangan antara Permintaan dan Penawaran

Berdasarkan hasil estimasi persamaan permintaan dan persamaan penawaran terhadap model regresi untuk keseimbangan antara permintaan dan penawaran makanan khas Langkitang di Pantai Padang dengan menggunakan program spss.16 diperoleh hasil regresi persamaan keseimbangan seperti yang terlihat pada tabel dibawah ini

Tabel 4. Hasil Regresi Keseimbangan antara Permintaan dan Penawaran

\begin{tabular}{|c|r|c|c|r|r|}
\hline Variable & Coefficient & Sig. & Variable & \multirow{2}{*}{ Coefficient } & \multicolumn{1}{c|}{ Sig. } \\
\cline { 1 - 4 } Permintaan & & & Penawaran & & \\
\hline Constant & 39.370 & 0.001 & Constant & 27.991 & 0.025 \\
\hline P & 0.890 & 0.039 & P & 0.019 & 0.040 \\
\hline Ps & -0.108 & 0.237 & Ps & -0.024 & 0.357 \\
\hline Y & 0.880 & 0.036 & C & 0.254 & 0.042 \\
\hline N & 0.115 & 0.751 & Tp & 1.241 & 0.001 \\
\hline
\end{tabular}

Berdasarkan Tabel diatas maka diperoleh persamaan sebagai berikut.:
1) $\mathrm{Q}_{\mathrm{d}}=39.370$ P fit $^{0,890} \mathrm{Ps}^{-}{ }^{0,108}$ $\mathrm{Y}^{1,880} \mathrm{~N}^{0,115}$ 
Kemudian nilai mean variabel $\mathrm{P}_{\mathrm{s}}(5.000), \quad \mathrm{Y}(2.250 .000), \quad$ dan $\mathrm{N}(29)$ di substitusikan ke persamaan di atas yang menghasilkan persamaan berikut:

$\mathrm{Q}_{\mathrm{d}} \quad=39,370 \quad \mathrm{P} \quad f i t^{0,890}(5000)-$ ${ }^{0,108} \mathrm{Y}(2.250 .000)^{0,880} \mathrm{~N}(29)^{0,115}$

$\mathrm{Q}_{\mathrm{d}}=39,370$ P fit ${ }^{0,890}(2,508)$ $(388,974)(1,472)$

$\mathrm{Q}_{\mathrm{d}}=39,370 \mathrm{P} f i t^{0,890}(1436,04)$

$\mathrm{Q}_{\mathrm{d}}=56.535,51 \mathrm{P} f i t^{0,890}$

$\mathrm{Q}_{\mathrm{d}}=56,535.10^{3} \mathrm{P} f i t^{0,890}$

2) $\mathrm{Q}_{\mathrm{s}}=27,991 \mathrm{Pfit}^{0,019} \mathrm{Ps}^{0}{ }^{0,024} \mathrm{C}^{0,254}$ $\mathrm{Tp}^{1,241}$

Kemudian nilai mean variabel $\mathrm{P}_{\mathrm{s}}$ (5.000), C (102.100), dan Tp (10) disubstitusikan ke persamaan di atas yang menghasilkan persamaan berikut:

$\mathrm{Q}_{\mathrm{s}}=27,991 \mathrm{P} f i t^{0,019}(5.000)^{-0,024}$ $(102.100)^{0,254} \mathrm{Tp}(10)^{1,241}$

$\mathrm{Q}_{\mathrm{s}}=27,991 \quad \mathrm{P} f i t^{0,019}(1,226)$ $(18,719)(17,418)$

$\mathrm{Q}_{\mathrm{s}}=27,991 \mathrm{P} f i t^{0,019}(399,734)$

$\mathrm{Q}_{\mathrm{s}}=11.188,95 \mathrm{P} f i t^{0,019}$

$\mathrm{Q}_{\mathrm{s}}=11,189.10^{3} \mathrm{P} f i t^{0,019}$

Berdasarkan hasil penelitian yang telah diolah, maka diperoleh hasil untuk ekuilibrium/keseimbangan sebagai berikut:

a) Pendekatan Matematika

Pendekatan matematika digunakan dalam mencari harga dan jumlah keseimbangan apabila data yang dimiliki berbentuk fungsi permintaan dan fungsi penawaran. Untuk mencari harga dan jumlah keseimbangan dari kedua fungsi tersebut, dapat menggunakan rumus syarat keseimbangan berikut:

$$
\begin{aligned}
& \begin{array}{c}
\text { Ekuilibrium }(\mathrm{E}) \quad=\mathrm{Q}_{\mathrm{d}}=\mathrm{Q}_{\mathrm{s}} \\
56,535 \cdot 10^{3} \mathrm{Pfit}
\end{array} \\
& 11,189.10^{3} \mathrm{Pfit}^{0,019} \\
& \mathrm{P} f i t^{0,909}=\frac{56,535 \cdot 10^{3}}{11,189 \cdot 10^{3}} \\
& \begin{array}{c}
\text { P fit }= \\
0,909 \sqrt{5,05273036} \cdot 10^{3}
\end{array} \\
& \mathrm{P} \text { fit }=5052,73 \mathrm{x} \\
& 0,909 \\
& \text { P fit }=4592,93
\end{aligned}
$$

(dibulatkan Rp. 4600/porsi)

$$
\text { Sehingga harga }
$$
keseimbangan $\mathrm{P}$ fit-nya adalah Rp. 4600 nilai tersebut merupakan nilai harga keseimbangan antara permintaan dan penawaran, sedangkan nilai outputnya yaitu harga keseimbangan disubstitusikan ke dalam salah satu persamaan permintaan dan persamaan penawaran, sebagai berikut:

Jika digunakan untuk persamaan permintaan:

$\mathrm{Q}_{\mathrm{d}}=56,535.10^{3} \mathrm{P} \mathrm{fit}^{0,890}$

$\mathrm{Q}_{\mathrm{d}}=56,535.10^{3}(4600)^{0,890}$

$\mathrm{Q}_{\mathrm{d}}=56,535.10^{3}(1819,091)$

$\mathrm{Q}_{\mathrm{d}}=56.535 /(1819,091)$

$\mathrm{Q}_{\mathrm{d}}=31,68$ (dibulatkan menjadi :32)

Jika digunakan untuk persamaan penawaran:

$\mathrm{Q}_{\mathrm{s}}=11,189.10^{3} \mathrm{P}$ fit $^{0,019}$

$\mathrm{Q}_{\mathrm{s}}=11,189 \cdot 10^{3}(4600)^{0,019}$

$\mathrm{Q}_{\mathrm{s}}=11,189.10^{3}(358,108)$ 
$\mathrm{Q}_{\mathrm{s}}=11.189 /(358,108)$

$\mathrm{Q}_{\mathrm{s}}=31,26$ (dibulatkan menjadi $: 32)$

Hasil output pada tingkat keseimbangan jika menggunakan persamaan permintaan dan persamaan penawaran menghasilkan nilai yang hampir sama \pm 550 porsi langkitang. Sehingga ekuilibrium per-mintaan $\left(\mathrm{Q}_{\mathrm{d}}\right)$ dan ekuilibrium penawaran $\left(\mathrm{Q}_{\mathrm{s}}\right)$ adalah 32 porsi dan harga ekuilibrium (P) adalah Rp. 4600.

b) Pendekatan Grafik atau Kurva

Untuk memperlihatkan secara jelas

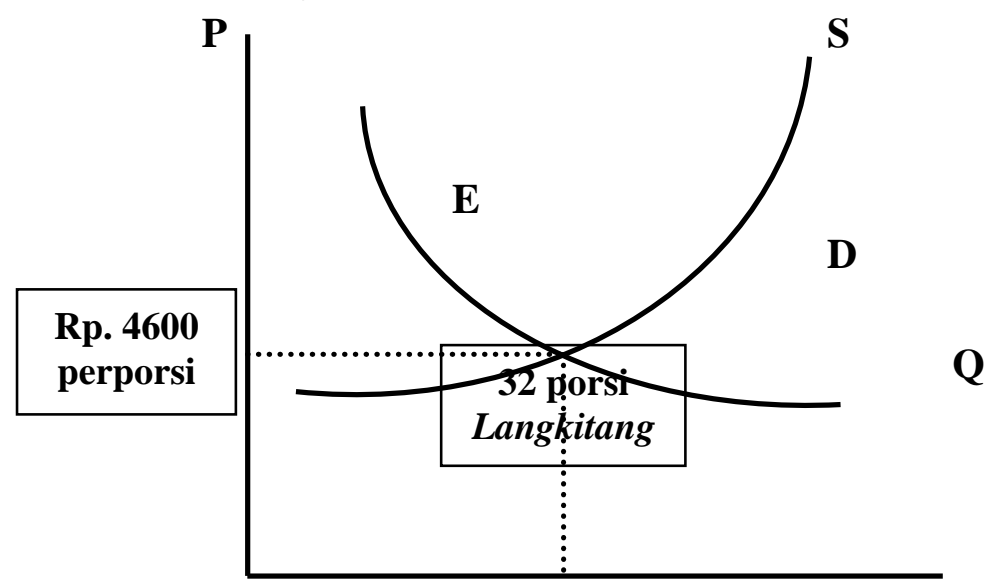

Gambar 1. Kurva Tingkat Keseimbangan Permintaan dan Penawaran Makanan Khas Langkitang di Pantai Padang

Berdasarkan kurva tingkat keseimbangan di atas, dapat disimpulkan bahwa keseimbangan antara permintaan dan penawaran makanan khas Langkitang pada harga Rp. 4600,- per porsi dan jumlah kuantitas sebanyak 32 porsi Langkitang. adanya ekuilibrium harga

(P) dan jumlah keseimbangan atau output ekuilibrium (Q) dari pendekatan matematika yang telah diuraikan sebelumnya, perlu dibuat sebuah kurva permintaan dan penawaran. Dari perpotongan kurva permintaan dan penawaran didapat titik keseimbangan (E). Pada kurva keseimbangan inilah dapat dilihat harga dan kuantitas keseimbangan secara jelas. Dapat dilihat pada gambar dibawah ini:

$\mathbf{Q}$ 
dikeluarkan sudah sepenuhnya kembali atau dengan istilah "Balik Modal".. Adapun rumus yang dapat digunakan dalam menghitung Break even point (BEP) sebagai berikut:

1) $\mathrm{BEP}($ Unit $)=$

Total Biaya rata-rata

Harga Jual

$$
=\frac{102100}{5000}=
$$

20,42 dibulatkan 21 porsi

Berdasarkan rumus BEP di atas diperoleh hasil perhitungan untuk BEP (unit) sebesar 21 porsi, dan hasil perhitungan untuk BEP (rupiah) sebesar Rp. 105.000. Artinya agar para pedagang balik modal, masingmasing pedagang harus menjual makanan khas Langkitang sebanyak 21 porsi perhari, sehingga akan diperoleh penjualan sebesar Rp.105.000,-.

\section{Pembahasan}

Hasil penelitian ini telah menemukan gambaran keseimbangan pasar antara permintaan dan penawaran makanan khas Langkitang di Pantai Padang.

Secara umum dapat dinyatakan bahwa permintaan dan penawaran makanan khas Langkitang telah menemukan titik keseimbangan yang dipengaruhi oleh beberapa faktor. Sesuai dengan teori menurut Sukirno (2002: 80-83), "Permintaan dipengaruhi oleh beberapa faktor yaitu: 1) harga barang itu sendiri, 2) harga barng substitusi, 3) pendapatan konsumen, dan 4) jumlah pembeli".
Kemudian menurut Sukirno (2002: 86), "Penawaran dipengaruhi oleh beberapa faktor yaitu: 1) harga barang itu sendiri, 2) harga barang substitusi, 3) biaya produksi, dan 4) jumlah produsen dipasar".

Berdasarkan hasil analisis yang dilakukan, masing-masing faktor memiliki angka yang menunjukan ada atau tidaknya pengaruh terhadap permintaan dan penawaran makanan khas Langkitang :

1. Harga barang itu sendiri (P)

Hasil estimasi persamaan simultan untuk permintaan dan penawaran menunjukan bahwa nilai koefisien dari harga produk Langkitang (P) berpengaruh positif dan signifikan, dengan nilai yaitu sebesar 0,890 untuk permintaan dan untuk penawaran sebesar 0,019, dengan signifikansi $<0,05$.

2. Harga barang substitusi (Ps)

Hasil estimasi persamaan simultan untuk permintaan dan penawaran menunjukan bahwa nilai koefisien dari harga barang substitusi (Ps) memiliki pengaruh yang negatif dan tidak signifikan terhadap permintaan dan penawaran makanan khas Langkitang di Pantai Padang yaitu untuk permintaan sebesar $-0,108$ dan untuk penawaran sebesar -0 , 024, dengan signifikansi >0,05.

3. Pendapatan konsumen (Y)

Hasil estimasi persamaan simultan untuk permintaan menunjukan bahwa nilai koefisien dari tingkat pendapatan konsumen 
(Y) memiliki pengaruh yang positif dan signifikan terhadap permintaan Langkitang di Pantai Padang yaitu sebesar 1,880, dengan tingkat signifikan $<0,05$.

4. Jumlah pembeli (N)

Hasil estimasi persamaan simultan untuk permintaan menunjukan bahwa nilai koefisien dari jumlah pembeli (N) memiliki pengaruh yang positif namun tidak signifikan terhadap permintaan Langkitang yaitu sebesar 0,115, dengan tingkat signifikansi $>0,05$.

5. Biaya produksi (C)

Hasil estimasi persamaan simultan untuk penawaran menunjukan bahwa nilai koefisien dari biaya produksi (C) memiliki pengaruh yang positif dan signifikan terhadap penawaran produk Langkitang di pantai Padang yaitu sebesar 0,254, dengan signifikansi $<0,05$.

6. Jumlah produsen dipasar (Tp) Hasil estimasi persamaan
simultan untuk penawaran
menunjukan bahwa nilai koefisien
dari jumlah produsen
dipasar/pesaing (Tp) memiliki
pengaruh yang positif dan
signifikan terhadap penawaran
makanan khas Langkitang di
Pantai Padang yaitu sebesar
1,241, dengan tingkat signifikan <
0,05 . Berdasarkan konsep keseimbangan pasar yang telah dijelaskan pada bab sebelumnya, menurut Nicholson (2002: 14), "Keseimbangan pasar merupakan harga yang terjadi ketika kuantitas barang yang diminta sama dengan kuantitas barang yang diawarkan oleh penjual". Sehingga permintaan dan penawaran secara bersama-sama akan menentukan harga $\left(\mathrm{P}^{*}\right)$ dan kuantitas keseimbangan dalam sebuah kurva $\left(Q^{*}\right)$.

Artinya, keseimbangan permintaan dan penawaran makanan khas Langkitang di Pantai Padang akan seimbang dengan harga yang lebih rendah yaitu sebesar Rp. 4600,dengan jumlah barang yang di minta secara tepat sama dengan jumlah barang yang di tawarkan yaitu sebesar 32 porsi Langkitang, dan keseimbangan pasar makanan khas Langkitang tersebut terjadi pada titik keseimbangan yang disebut titik E (ekuilibrium).

\section{Pada analisis Break Event} Point (BEP) diperoleh hasil perhitungan untuk BEP (unit) sebesar 21 unit, dengan pendapatan sebesar Rp 105.000,-. Artinya agar para pedagang balik modal, masingmasing pedagang harus mampu menjual makanan khas Langkitang sebanyak 21 porsi setiap harinya.

\section{KESIMPULAN DAN SARAN}

\section{A. Kesimpulan}

Berdasarkan uraian yang telah disusun pada bagian sebelumya dan sesuai dengan data yang diperoleh selama penelitian, maka dapat diambil kesimpulan dari hasil penelitian ini sebagai berikut:

1. Faktor-faktor yang mempengaruhi permintaan makanan khas 
Langkitang di Pantai Padang memiliki koefisien elastisitas yang berbeda-beda. Berdasarkan hasil penelitian ternyata faktor harga (P) dan pendapatan konsumen $(\mathrm{Y})$ berpengaruh signifikan terhadap permintaan makanan khas Langkitang.

Sedangkan faktor harga produk subsitusi (Ps) yaitu Pensi memiliki pengaruh negatif dan tidak signifikan, sementara itu faktor jumlah pembeli (N), memiliki pengaruh yang positif namun tidak signifikan terhadap permintaan makanan khas Langkitang di Pantai Padang.

2. Faktor-faktor yang mempengaruhi penawaran makanan khas Langkitang di Pantai Padang memiliki koefisien elastisitas yang berbeda-beda. Berdasarkan hasil penelitian ternyata faktor harga (P), faktor biaya produksi makanan khas Langkitang (C) dan faktor Jumlah penjual/pesaing (Tp) memiliki pengaruh Positif dan signifikan terhadap penawaran makanan khas Langkitang di Pantai Padang, sementara itu faktor harga barang pengganti (Ps) yaitu produk makanan Pensi memiliki pengaruh yang negatif dan tidak signifikan terhadap penawaran Langkitang di Pantai Padang.

Berdasarkan hasil penelitian ini dapat ditegaskan bahwa permintaan dan penawaran makanan khas Langkitang di Pantai Padang telah mencapai titik keseimbangan pasar, yang berada pada harga keseimbangan sebesar Rp. 4600,perporsinya dengan kuantitas keseimbangan sebesar 32 porsi. Artinya harga keseimbangan akan menentukan kuantitas keseimbangan antara permintaan dan penawaran makanan khas Langkitang di Pantai Padang. Titik impas atau Break even point (balik modal) berada pada penjualan sebanyak 21 porsi Langkitang dengan pendapatan sebesar Rp. 105.000,--

\section{B. Saran}

a. Para produsen dalam menentukan harga, perlu memperhatikan besarnya permintaan yang ada sehingga harga yang ditentukan dapat terjangkau oleh semua konsumen. Selain itu, produsen juga perlu memperhatikan tingkat pendapatan konsumen, karena semakin tinggi tingkat pendapatan konsumen, maka daya beli konsumen juga ikut meningkat, begitupun sebaliknya. Para produsen harus memperhatikan kuantitas permintaan dari konsumen agar dapat seimbang dengan kuantitas yang ditawarkan. Guna memaksimalkan keuntungan yang diterima dan meminimalkan kerugian.

b. Untuk meningkatkan penjualan makanan khas Langkitang perlu diperhatikan kualitas produk yang ditawarkan sehingga produk tersebut disukai oleh konsumen.

c. Peneliti berikutnya yang ingin melakukan penelitian lebih lanjut sebaiknya diungkapkan variabel- 
variabel lain yang relevan seperti:

pengaruh harga tehadap keputusan pembelian makanan khas Langkitang, analisis kualitas produk makanan khas Langkitang, serta faktor-faktor lainnya tang tentunya berpengaruh terhadap permintaan makanan khas Langkitang di Pantai Padang, seperti kualitas pelayanan, lokasi, dan lainnya.

\section{DAFTAR PUSTAKA}

Nicholson, Walter. 2002. Teori Ekonomi Mikro Penterjemah Deliarnov. Jakarta:

PT. Raja Grafindo Persada

Puspita, Wulan. 2015. Kualitas dan Daya Terima Sala Lauak dengan Penambahan Bayam Dan Ikan Segar Sebagai Makanan Anak Balita.Padang: Universitas Negeri Padang.

Sukirno, Sadono. 2002. Pengantar Teori Microekonomi. Edisi Ketiga. Jakarta: PT. Raja Grafindo Persada.

Sumodininggrat, Gunawan. 2007. Ekonometrika Pengantar. Yogyakarta: BPFE.

Triyahayu, Refika. 2012. Analisis Permintaan dan Penawaran Kopi di Indonesia (Skripsi). Padang: Universitas Negeri Padang.

Yoeti, Oka A. 2008. Perencanaan dan Pengembangan Pariwisata. Jakarta: Pradnya Paramita. 